\title{
Social Skills and Academic Performance among Grade 10 Students of the University of Bohol - University High School
}

\author{
FREDERICK E. PAROGINOG \\ http://orcid.org/0000-0002-9888-7951 \\ paroginogfrederick@gmail.com \\ MARIBETH DUSAL-ALPUERTO \\ http://orcid.org/0000-0003-4849-3652 \\ mdalpuerto@universityofbohol.edu.ph \\ LEAH WILFREDA RE. PILONGO \\ http://orcid.org/0000-0001-6380-1831 \\ leahechavez@universityofbohol.edu.ph
}

\section{ABSTRACT}

Social skills are a set of behaviors manifested by individuals in an interpersonal context in which they express feelings, attitudes, desires, opinions or rights suitable for the situation, respecting the same action in others with the dimensions of self-control, empathy, assertion, and cooperation. Academic performance in this study is measured according to the general average of the second grading period of School Year 2017-2018 of the Grade 10 Junior High students of the University of Bohol - University High School (UB-UHS) in Tagbilaran City, Bohol, Philippines. This study intends to determine the level of social skills between the said students, in relation to their academic performance for the school year 2017-2018. This study made use of a quantitative method, specifically the descriptive-survey technique with the aid of the questionnaire to gather the level of social skills among the respondents. Results showed all respondents had a Moderate level of all 
the dimensions of social skills. Noteworthy to mention was their greater propensity to exercise Cooperation, followed by a tie in Empathy and Self-Control and last was Assertion. There was a significant relationship between sex and academic performance. When comparing the four dimensions of social skills using ANOVA, there was a significant variance of the four dimensions. When further tested using Scheffe's Test, the pairings revealed significant difference on Self-Control and Empathy, between Self-Control and Cooperation, between Empathy and Assertion, between Empathy and Cooperation and Assertion and Cooperation. However, insignificant result was found between Self-Control and Assertion. Hence, a need to focus on more intensive programs on developing Social Skills for the students to develop and hone a well-balanced personality.

Keywords: Basic education, social skills, academic performance, quantitative method, Chi-Square, Pearson Product Moment, ANOVA, Philippines, Asia

\section{INTRODUCTION}

Adolescence is one of the critical periods across the lifespan as it posted enormous challenges in emotional development and social identity. This stage also depicts an increase in the intricacy of group interactions. Thus, social behavior is an imperative (Lerner \& Steinberg, 2004). As Coleman and Hendry (1990) pointed out, adolescence is also a developmental period where consolidation of the social self, of one's identity and understanding of the self in relation to the social world, is being highlighted. At this very stage, social skills are considered as a very important component in a student's emotional health and wellbeing.

Social skills are part and parcel of behavior that facilitates an individual's understanding and adaptation across a variety of social settings. Further, social skills are considered as fundamental factors for the relationship ormation, or the quality o social interactions and even or the individual's mental health (Hay, 1994). As noted by Zins, Bloodworth, Weissberg, and Walberg (2007), "Schools are social places, and learning is a social process." Students are learning from teachers and peers, and the utilization of emotions facilitate the learning process; it is pointed out that the Social-Emotional Learning (SEL) is a requirement to optimize not only the success of children in social relations 
and personal well-being but also their more extensive adjustments in schools and classrooms which eventually leads to academic achievement.

The American Psychological Association stressed that positive social skills are critical to successful functioning in life. These skills are determinant for individuals to know what to say, how to attain good choices, and how to behave appropriately in diverse situations. The extent to which both children, adolescents, and youth possess those needed social skills can influence their academic performance, behavior, social and family relationships, and involvement in extracurricular activities. Social skills are specific behaviors that behaviors that people manifest to complete successfully social tasks, whereas social competence represents judgments by significant others that these social tasks were accomplished (Del Prette \& Del Prette, 1999).

Social and cognitive development is supported by emotional skills among young children (Denham, 2007). The study stipulated that emotional knowledge is a predictor of academic competence and task orientation in the middle childhood, the verbal ability is being controlled (Izard, 2001). Also, adolescents' poor emotional competence is a predictor of school difficulties being associated with underachievement in academic tasks which eventually leads to school drop-out and antisocial behavior (Gagnon, Craig, Tremblay, Zhou, \& Vitaro, 1995). Hence, with this results, emotional functioning is associated with academic performance and success. Further, associations are found between ability and traitemotional intelligence (EI) and academic achievement among British adolescents in mainstream education.

Academic performance in this study was measured according to the general average of the Grade 10 Junior High students of the UB University High School for the second grading period of school year 2017-2018. In several cases, the combination of a lack of social and academic study skills were more likely to become impediments to students' to aspire for academic success during their high school years.

This researchers made a contention that without social skills; there is lack of maturity of student's academic skills to the necessary level to attain a successful high school experience. It further assessed if the socio-demographic variables have the potential to influence social skills during junior high adolescents. Finally, the study explained when such topic explored its impact on academic performance. Further, the study intended to take a look at what to say about social skills interven- 
tions and programs for adolescent students.

Typical problems encountered by educational leaders, teachers, school guidance counselors and school psychologists were academically low or underperforming students due to lack of proper social skills, to name, lack of attention and preparation during class hours, being aggressive towards classmates and school authorities, unable to engage in cooperative learning and general disruptive behavior within the classroom. The lack of social skills has yielded to adverse consequences in the academic performance that were measured as results of quizzes, results of schoolwork, issues on tardiness and absenteeism, and the incapability to sustain social relationships among classmates. Also, the impact of the lack of social skills on the student academic skills have shown to exist in the student's ability to engage in proper studying skills, problem-solving, decisionmaking, content mastery, performance skills, and task management skills. These actions led to low academic performance. Those students who had difficulties with those inappropriate behaviors and fail to master social skills were more likely to face disciplinary actions specified in the school manual. Outcomes in this study will feed programs and policies in the Junior and Senior High School and even in the lower levels of basic education within and outside the University for an evidence-based programmatic measures. A need for the university adolescents to be guided, directly and systemically, the most fitting social skills to succeed in school which is a preparation for life. Moreover, a need for the children the completion of academic tasks through strategic reinforcement by focusing on persistence, self-motivation to fully engage into life-learning (Martens \& Witt, 2004).

The research builds on the study of Comedis' titled "The Role of Social Skills on the Academic Performance of De La Salle Araneta University Freshmen Students: Creating Culture (2014). The study is anchored in the theories of G. Stanley Hall's adolescent's storm and stress; of behaviorism which is postulated by B. F. Skinner, and Social Learning Theories.

The period of adolescence has been considered as "storm and stress" by $\mathrm{G}$. Stanley Hall has been generating debates on the developmental framework more than a century. As pointed out by Waltz (1927), Hall coined in 1904, the term "storm and stress" which was taken from the Sturm and Drang literary movement sometime in the late 18th century. Translations of such phrase included storm and pressure, which have connotations 
of excessive emotionality or strong inspiration. The trio of "storm and stress" domains as espoused by Arnett (1999) namely, conflict, mood, and risk-taking which he elaborated that each of which are manifestations of several emotional processes. The onset of the changes in the behavior of adolescents involved two interrelated processes: emotional arousal and emotion regulation (Steinberg, 2008, 2010).

The theory of Behaviorism by B.F. Skinner upon which learning happens at the acquisition of overt behavior, this study is being anchored. Skinner's theory is based on the premise that behavior that leads to a satisfying state of affairs tend to be repeated. An experiment he made on rats in his laboratory applying the stimulus and response (S-R) connection, upon which led to the change of the rat's behavior. It led to the views that if rat's behavior can be changed, then so with the behavior of humans. In this perspective, behaviorists capitalized on learning as a change of behavior and mental processes. B.F. Skinner further postulated that mind has nothing to do with learning; it asserts that learning is the acquisition of new behavior (Skinner, 1950).

Further, behaviorists base learning on observable behavior. According to Skinner (1968), "Teachers must learn how to teach ... they need only to be taught more effective ways of teaching." He advocates that establishing and changing behavior is more effective when positive reinforcement is applied than punishment. Such evidence was observed as implications for prevalent practices of rote learning and punitive discipline in the teachinglearning process. Skinner added that the primary aspect that people learn from undergoing punishment is the avoidance of such in the future (McLeod, 2007).

Human behavior theorists, Lev Vygotsky and Albert Bandura, supported this particular study. They purported the interplay of human behavior and learning as influencers of social behavior on cognitive functioning. Vygotsky (1978) suggested that social functioning with peers is not only a positive influence but is essential in the acquisition of new skills and ideas. Bandura's social cognition theory also contributed to the support of the causal relationship between social behavior and academic success. As Bandura (1997) pointed out, there are several ways that children are learning. One of the learning instances through observation of others which eventually lead to imitating people around them, or by merely listening to others. 
Also, learning can also be mediated through internal self-regulation that evolves by learning from the influences from the environment, such as the young can be very observant from what behaviors are being reinforced or punished when done by other children, and when to discriminate properly between appropriate and inappropriate uses of a particular behavior.

Bandura tied up his contention that an interaction between child's behavior and the environment. His theory stressed that learning is a social process which can be dissected according to context. He viewed learning all types of behavior that include academic skills as being mediated by influences of the environment. Bandura would interject that after the occurrence of a skill achievement, such achievement would affect the behavior of the child. As an aftereffect, although he asserted reciprocal determinism, it shows that his suggested theory depicts the cycle conceives with the social context that affects acquisition of new skills. This manifestation can be observed in the array of learning that occurs in the classroom activities being depicted as cooperative learning (Johnson \& Johnson, 1975). Across the years, theorists and academicians have propelled the positive academic effects of cooperative learning methodologies. Cooperative learning can be perceived of incorporating the ideas of Bandura and Vygotsky. One of the success stories of social psychology is the extensive utilization of cooperative learning which is now considered a standard educational practice in almost elementary and secondary schools, and various colleges and universities in Canada, the United States, and other countries across the globe. To understand better how social psychological theory and research has revolutionized teaching practices, it is necessary to understand mainly what cooperative learning is (Slavin, 1995). A realization that in working cooperatively, students are responsible mutually for each other's learning and the reflection that they have a stake in each other's success.

Any assignment in any curriculum for any age student can be done cooperatively. For instance, Vygotsky ascertained that children working cooperatively together would acquire more skills when they were working alone since those children of the same ages would be behaving within each other's Zone of Proximal Development (ZPD) (Slavin, 1995). Again, as illustrated by a particular and popular instructional practice, the exhibition of socially and cognitively appropriate groups of children is said to lead to more positive academic outcomes. This method is not designed to teach social behaviors but assumes that children already have social behaviors 
in their repertoire. Cooperative learning acts to provide a context to exhibit those behaviors to facilitate learning.

A primary component of cooperative learning, positive interdependence, is attained when every member of a group comes to understand and manifest the need for group cooperation in the achievement of their personal goals, the other member's goals, and the goals of the whole group (Chaiklin, 2003). Interdependence may be in the form of the interconnectedness of goal, task, resource, role, or reward. The positive interdependence outcomes happen when students are more highly motivated to work cooperatively when task success depends on the participation of other group members.

The second component of cooperative learning is face-to-face interactions, which works in conjunction with positive interdependence. Face-to-face interactions involve individual group members facilitating and encouraging other group members' efforts to task completion and the attainment of goals in a group. The accountability of each member in a group is the third basic element of cooperative learning. It involves letting each one accountable for mastering relevant and meaning material. Individual accountability covers both completion of one's task within the group and supporting the work of other group members. According to Johnson, Johnson, Holubec, \& Roy (1984), "The purpose of a learning situation is to maximize the achievement of each student. Determining the level of mastery of each student is necessary so students can provide appropriate support and assistance to one another." Individual accountability at the same time avoids situations where selected group members do most of the work while some others become "freeloaders."

For several decades, researchers conducted studies on Social learning theory that is a combination of cognitive learning theory and behavioral learning theory, which emphasized on self-regulatory processes as selfreinforcement (Bandura, Grusec, \& Menlove, 1967) and self-evaluation (e.g., Bandura \& Cervone, 1983). Bandura integrated these two theories and came up with four requirements for learning: observation (environmental), retention (cognitive), reproduction (cognitive), and motivation (both). This integrative approach to learning was called social learning theory.

The ability of a human being to exercise self-control is considered one of the most essential and beneficial capacity to adapt to the human mind. The happiest and healthiest people when looking into the optimum fit between people themselves and environment and the 
possibility to improve substantially by changing the self to fit the world. (Rothbaum, Weisz, \& Snyder, 1982). As for self-control, a very good measure of a trait of this particular construct was created as to the published evidence among adults that indicated that researchers were not satisfied utilizing the existing scales. Latest discoveries in the theory of self-control (Carver \& Scheier, 1981, 1998; also Baumeister, Heatherton, \& Tice, 1994) presupposed the importance of the coming up with new scales that were negated to those who relied on the traditional measures. For instance, a study conducted by Baumeister et al. (1994) singled out four crucial domains of self-control, namely, controlling the thoughts, how one feels, impulses, and performancewhich are considered essential to making use in coming up in an overall index of self-control. Longitudinal studies conducted by Mischel, Shoda \& Peake (1988), as well as Shoda, Mischel \& Peak (1990), further relates that sufficient capacity to delay gratification at four-year of age is more likely to have better interpersonal early adulthood relationships.

Primary to the idea of self-control is the capacity to supersede one's inner responses, and also to interrupt the undesirable behavioral tendencies and do away from acting them out. With this particular view, self-control would lead to contributing a wide range of positive gains in life. As empirical evidence shows, individuals with high dispositional selfcontrol have better chances of favorable outcomes in various spheres. Findings show that people with high self-control should be expected to achieve better grades in the long run, as they can do tasks better on time, they avoided being derailed by leisure activities to interfere with their work, they used to study time effectively, they appropriately chose courses, and kept emotions from distracting their performance.

Rothbaum et al., (1982) pointed out that exerting self-control is one of the most prominent and advantageous ability to adapt among humans. The attribution that people are healthiest and happiest when there is an optimum match between the self and the environment, such fit can be meaningfully and significantly improved by changing the self to fit the world. Further, high self-control is expected to make better persons, leads to high desirability regarding relationships and most likely to contribute to success in relationships in many ways. Other than those mentioned, it is also contributory to harmonious interactions since people avoid impulsive words that hurt the feelings of others (Tangney, Boone, \& Baumeister, 2018). 
In a study by Tice and Baumeister (1997), self-control is one of the determinants to attain better grades. Such findings affirmed the advocates of self-discipline on their speculations that such trait produces better task performance. Vice-versa, individuals with poor self-control, tend to procrastinate on delivering tasks which are reasons to lower or poorer task performance and lower grades. As several studies pointed out, various university students have difficulties in impulse regulation, as widely documented (Baumeister et al., 1994). Particularly, prevalence on problems with regulating eating among female university students, on the other hand, surveys conducted to male students suggested that some had issues of alcohol abuse (e.g., Heatherton, 1993; Heatherton \& Baumeister, 1991). Regulating intake of food and drink is one of the most obvious and direct applications of self-control, and so we predicted that people high in self-control should exhibit fewer such problems.

The persuasion which also means assertion and influence are essential skills for attitude change or others' behaviors in a desirable direction. Individual differences matter because others may not share one's views and may often behave differently from ways one prefers, most try to influence the attitudes, beliefs, or behaviors of others day by day (Baron \& Markman 2000).

A study conducted on "Children's Social Behaviors as Predictors of Academic Achievement: A Longitudinal Analysis where it looked into the relationships among a diverse sample of elementary students' social skills, problem behaviors, academic competence, and academic achievement. It was found that social skills are positively predictive of concurrent academic achievement (Malecki \& Elliott 2002).

Empathy is the tendency to experience others' emotions. Most clinical and counseling psychologists agree that true empathy requires three distinct skills, the ability to share the other person's feelings, the cognitive ability to intuit what another person is feeling, and a "socially beneficial" intention to respond compassionately to that person's distress (Decety \& Jackson, 2004).

From a developmental point of view, empathy is perceived as a basic dimension of social interaction. It has been a point of argument that the ability to empathize with children has an essential role in the development of moral judgment, pro-social behaviors, and childhood social competence (Thompson 1987). Such ability depends functionally on several basic processes that include the ability to perceive visual cues accurately within 
interpersonal contexts (Minter, Hubson \& Pring 1992, Dyck, Ferguson, Shochet 2001). As a result, children's inability to perceive visual or other sensory cues accurately limits their ability to decode and label the emotional expressions of other people, a key component in the ability to understand the experience of others.

Research literature highlighted the importance of learning-related social skills for early school adjustment and success. As Ladd, Birch \& Buhs (1999) found out, classroom participation of children and their cooperative ability was a significant predictor of early school achievement. Another study by Foulks and Morrow (1989) also showed that teachers claimed, learning-related skills such as listening to instructions and directions, and compliance with teacher demands, were most important for success in kindergarten. Lastly, Bronson, Tivnan, \& Seppanen (1995) found that prekindergarten children who spent more time uninvolved in the classroom and had difficulty with rules or with the teacher had lower scores on a standardized cognitive achievement measure.

A study of Wong, Day, Maxwell and Meara 1995 sought to find out the relationship between academic success and emotional and social competencies. It found that social perception which is the ability to understand the emotional states of other people was considered a moderate predictor of academic performance among university students. Such study used GPA as an indicator of academic success. A preliminary study of emotional intelligence, empathy and exam performance in firstyear medical students (Austin, Evans, Goldwater, \& Potter, 2005), Apart from cognitive ability, considerable interest was raised as to the attributes of empathy, and emotional intelligence among medical students need to be successful professionally. Previous reports showed that there is a decline in empathy among US medical students. However, no comparative information is available for UK students. The study intended to compare the levels of empathy among year levels $2,3,5$, at the same time to find out gender differences of the same and its relation to academic success. Empathy trends were examined using analysis of variance and Pearson correlation. Results showed that gender caused differences in levels of empathy. There was no significant association found between empathy and academic performance. Research conducted by Wong et al., (1995) found out that the ability to understand the emotional states of other people was a moderate predictor of academic performance among university students where the GPA was used as an indicator of academic success. 
Another study by Van Rooy, Alonso, \& Viswesvaran (2005) gave the findings that higher scores on Emotional Intelligence are often, although not invariably, associated in females, although females were found to score higher for empathy than males as pointed out by studies done by Hoffman (1977) and Hojat, Mangione, Nasca, Cohen, Gonella, \& Erdmann (2001). This finding raises the possibility that El and/or empathy levels may be a contributory factor to male/female differences in academic success. However, result in the study of Austin et al., (2005) found out that empathy scores were not significantly correlated with any exam scores.

The inclusion of all versions is Cooperation, Assertion, and SelfControl social skills subscales. Noteworthy to mention is that the utility of this measure cuts across not only Junior High School respondents on self-management but also their skills in the realms of social awareness, responsible decision making, and relationship skills. The advantage of these measures are notably essential because these measures cut across not just the characteristics of self-management, but so with the skills in the areas of social awareness, owning the responsible making a decision and, and so with the relationship skills (Denham \& Brown 2010).

This study intends to determine the level of social skills among the Grade 10 students of the University of Bohol, Tagbilaran City, in relation to their academic performance for the school year 2017-2018. The findings will serve as the basis for recommendations. Specifically, it seeks to answer the following questions:

1. What is the level of social skills among the respondents in the following dimensions:

1.1. Self-control;

1.2. Empathy;

1.3. Assertion; and

1.4. Cooperation?

2. What is the level of academic performance among the respondents based on grade on the second grading period?

3. Is there a significant degree of relationship between profile and the following:

3.1 social skills; and

3.2 academic performance?

4. Is there a significant degree of correlation between social skills and academic performance? 
5. Is there a significant degree of variance on the four dimension of social skills among the Grade 10 students of the University High School, University of Bohol?

6. Based on the findings, what recommendations may be formulated?

\section{METHODOLOGY}

This study made use of a quantitative method, specifically the descriptive-survey technique with the aid of the questionnaire to gather the level of social skills among the Grade 10 students of the University of Bohol. The researcher made use of documentary analysis to secure the academic performance among the respondents based on their grades in the second grading period of school year 2017-2018.

Data mining was used in gathering the academic performance of the Grade 10 Junior High School students of the University of Bohol. Proper routing of communications to undertake the protocol in securing the grades of the second grading period of the students in the same University. Details were given on the appropriate section in this methodology.

The respondents of the study were the Grade 10 students of the University of Bohol. Complete enumeration was supposedly used as to the number of respondents that should have been included in the study. However, out of the 147 total population of the department, only 80 questionnaires were distributed since only those who were willing to undertake the survey were given the tool. In other words, those who participated constituted 67 percent of the total population as reflected in Table 1. Of the 80 questionnaires distributed, there was a 100 percent retrieval rate done by the researchers (See Table 2).

There were 24 samples (50\%) out of 48 number of students in the Diligence section. It was followed by 31 samples $(62 \%)$ out of 50 in Fidelity class, and 25 samples (51\%) out of 49 total number of students in Fortitude section.

As to the profile of the 80 Grade 10 Junior High School respondents included in the study, the majority or more than two-thirds $(65 \%)$ were at the age of 16 . Next, were the 15 year old students $(22.50 \%)$. The least numbers of respondents were at the ages of $14(1.25 \%)$ and 18 $(1.25 \%)$ respectively. The mean was 15.80 among the respondents (See Table 3). 
As to sex, the majority of the respondents were females $(68.75 \%)$. When looking into the three sections that they enrolled, slight differences were observed as to the respondents in each section. The biggest percentage came from Fidelity section $(38.75 \%)$, followed by Fortitude section $(31.25 \%)$ and lastly, the section Diligence (30\%).

This research study adapted a survey questionnaire from the study of Social Skills Rating Systems (SSRS) by Gresham \& Elliott (1990) to obtain the needed information pertaining to the social behaviors of Junior High School respondents on the four dimensions of Social Skills. The items on each dimension were rated according to perceived frequency and importance. There are three scales. The Social Skills Scale measures positive social behaviors: cooperation, empathy, assertion, and self-control. The tool was also adapted by Comedis (2014) in her study entitled "The Role of Social Skills in the Academic Performance of De La Salle Araneta University Freshmen Students: Creating a Culture." The researcher communicated with the said author and sought her permission to utilize her tool which she gladly responded to allow. She also agreed to take on as an external expert on the way to publication of the said paper. The questionnaire had an estimated 30 minutes time to complete.

Furthermore, as a protocol before the conduct of the study the research methodology and questionnaire underwent the exhaustive scrutiny of the panel of experts of the University Research Ethics Committee to see through that the "do no harm" will be ensured in the whole conduct of the study. After the whole administrative procedure for the approval of the conduct, it was ensured that consent from parents and assent from the students who were below 18 years old of age were secured through letters which were sent to the prospect respondents who affixed their signatures if they were willing to undergo the survey. Further, upon the permission of parents, letters of assent were given to the prospect respondents who were below 18 years of age. Both routings of communications informed the parents and the respondents of the objectives of the research, and they can stop answering at any point when they feel that their rights are violated.

Data on the profile, social skills sub-categories of self-control, cooperation, assertion, and empathy were subjected to statistical treatments; those were analyzed, compared and checked for similarities or differences utilizing the Statistical Package for the Social Sciences (SPSS). The simple percentage formula was used to determine the profile of the respondents in terms of age, sex, and section. The responses of 
the respondents were checked according to the correct answers for each question. The correct answers were summed up and categorized to determine the level of frequency of manifestations.

Weighted Mean was used to measure the central tendency where some values were given importance over others. This was used to gauge the average value of responses to items in the questionnaire. Academic performance of the respondents was analyzed utilizing the level of academic performance and rating. To test the hypothesis of this study, Chi-square test, Pearson Product Moment of Correlation, one-way Analysis of Variance and Scheffe's test were used.

\section{RESULTS AND DISCUSSION}

This section deals with the presentation, analysis, and interpretation of data gathered from the survey conducted among the Grade 10 Junior High respondents of the University High School Department, and so with their corresponding academic performance for the second grading period of school year 2017-2018.

\section{Level of Social Skills}

As to the levels of Socials skills among the Grade 10 respondents, it tackled the four dimensions which are the self-control, empathy, assertion, and cooperation.

Table 1. Level of social skills of respondents

$$
\mathrm{N}=80
$$

\begin{tabular}{|c|c|c|c|c|c|c|c|c|}
\hline Items & $\begin{array}{l}\text { Always } \\
(4)\end{array}$ & $\begin{array}{l}\text { Some- } \\
\text { times } \\
(3)\end{array}$ & $\begin{array}{l}\text { Often- } \\
\text { times } \\
(2)\end{array}$ & $\begin{array}{l}\text { Never } \\
\text { (1) }\end{array}$ & $\mathbf{N}$ & WM & $\begin{array}{l}\text { Interpre- } \\
\text { tation }\end{array}$ & Rank \\
\hline \multicolumn{9}{|l|}{ SELF-CONTROL } \\
\hline $\begin{array}{l}\text { 1. I do nice things for my parents } \\
\text { like helping with households } \\
\text { chores without being asked }\end{array}$ & 20 & 13 & 47 & 0 & 80 & 2.66 & Moderate & 8 \\
\hline 2. I make friends easily & 22 & 15 & 43 & 0 & 80 & 2.74 & Moderate & 4.5 \\
\hline 3. I follow the teacher's directions & 34 & 12 & 34 & 0 & 80 & 3.00 & Moderate & 1 \\
\hline $\begin{array}{l}\text { 4. I end fights with my parents } \\
\text { calmly }\end{array}$ & 24 & 27 & 23 & 6 & 80 & 2.86 & Moderate & 3 \\
\hline $\begin{array}{l}\text { 5. I compromise with parents } \\
\text { or teachers when we have a } \\
\text { disagreement }\end{array}$ & 16 & 27 & 35 & 2 & 80 & 2.71 & Moderate & 6.5 \\
\hline $\begin{array}{l}\text { 6. I disagree with adults without } \\
\text { fighting or arguing }\end{array}$ & 17 & 31 & 26 & 6 & 80 & 2.74 & Moderate & 4.5 \\
\hline
\end{tabular}




\begin{tabular}{|c|c|c|c|c|c|c|c|c|}
\hline Items & $\begin{array}{l}\text { Always } \\
\text { (4) }\end{array}$ & $\begin{array}{l}\text { Some- } \\
\text { times } \\
(3)\end{array}$ & $\begin{array}{l}\text { Often- } \\
\text { times } \\
(2)\end{array}$ & $\begin{array}{l}\text { Never } \\
(1)\end{array}$ & $\mathbf{N}$ & WM & $\begin{array}{l}\text { Interpre- } \\
\text { tation }\end{array}$ & Rank \\
\hline $\begin{array}{l}\text { 7. I control my temper when } \\
\text { people are angry with me }\end{array}$ & 25 & 25 & 30 & 0 & 80 & 2.94 & Moderate & 2 \\
\hline $\begin{array}{l}\text { 8. I take criticism from my parents } \\
\text { without getting angry }\end{array}$ & 16 & 29 & 31 & 4 & 80 & 2.71 & Moderate & 6.5 \\
\hline Composite Mean & & & & & & 2.80 & Moderate & \\
\hline \multicolumn{9}{|l|}{ EMPATHY } \\
\hline $\begin{array}{l}\text { 1. I stand up for my friends when } \\
\text { they have been unfairly } \\
\text { criticized }\end{array}$ & 32 & 14 & 33 & 1 & 80 & 2.96 & Moderate & 7 \\
\hline $\begin{array}{l}\text { 2. I feel sorry for others when bad } \\
\text { things happen to them }\end{array}$ & 51 & 11 & 18 & 0 & 80 & 3.41 & High & 2 \\
\hline $\begin{array}{l}\text { 3. I listen to my friends when they } \\
\text { talk about problems they are } \\
\text { having }\end{array}$ & 64 & 7 & 9 & 0 & 80 & 3.69 & High & 1 \\
\hline $\begin{array}{l}\text { 4. I try to understand how my } \\
\text { friends feel when they are } \\
\text { angry, upset, or sad }\end{array}$ & 33 & 19 & 25 & 3 & 80 & 3.03 & Moderate & 6 \\
\hline $\begin{array}{l}\text { 5. I let friends know I like them by } \\
\text { telling or showing them }\end{array}$ & 36 & 14 & 27 & 3 & 80 & 3.04 & Moderate & 5 \\
\hline $\begin{array}{l}\text { 6. I say nice things to others when } \\
\text { they have done something well }\end{array}$ & 39 & 16 & 25 & 0 & 80 & 3.18 & Moderate & 4 \\
\hline $\begin{array}{l}\text { 7. I try to understand how my } \\
\text { friends feel when they are } \\
\text { angry, upset, or sad }\end{array}$ & 47 & 9 & 24 & 0 & 80 & 3.29 & High & 3 \\
\hline Composite Mean & & & & & & 3.23 & Moderate & \\
\hline \multicolumn{9}{|l|}{ ASSERTION } \\
\hline $\begin{array}{l}\text { 1. I start talks with classroom } \\
\text { members }\end{array}$ & 25 & 28 & 26 & 1 & 80 & 2.96 & Moderate & 1 \\
\hline $\begin{array}{l}\text { 2. I start conversations with } \\
\text { opposite-sex friends without } \\
\text { feeling uneasy or nervous }\end{array}$ & 25 & 20 & 32 & 3 & 80 & 2.84 & Moderate & 3 \\
\hline $\begin{array}{l}\text { 3. I ask friends for help with my } \\
\text { problems }\end{array}$ & 27 & 20 & 31 & 2 & 80 & 2.90 & Moderate & 2 \\
\hline 4. I ask someone I like for a date & 2 & 23 & 6 & 49 & 80 & 1.73 & Low & 6 \\
\hline $\begin{array}{l}\text { 5. I give compliments to members } \\
\text { of the opposite sex }\end{array}$ & 12 & 35 & 24 & 9 & 80 & 2.63 & Moderate & 5 \\
\hline $\begin{array}{l}\text { 6. I talk things over with } \\
\text { classmates when there is a } \\
\text { problem or an argument }\end{array}$ & 11 & 37 & 32 & 0 & 80 & 2.74 & Moderate & 4 \\
\hline Composite Mean & & & & & & 2.63 & Moderate & \\
\hline \multicolumn{9}{|l|}{ COOPERATION } \\
\hline 1. I ask friends to do favors for me & 19 & 22 & 39 & 0 & 80 & 2.75 & Moderate & 5 \\
\hline $\begin{array}{l}\text { 2. I ask before using other } \\
\text { people's things }\end{array}$ & 44 & 14 & 22 & 0 & 80 & 3.28 & High & 2 \\
\hline 3. I keep my desk clean and neat & 36 & 20 & 20 & 4 & 80 & 3.10 & High & 3.5 \\
\hline 4. I finish classroom work on time & 10 & 29 & 40 & 1 & 80 & 2.60 & Moderate & 6 \\
\hline $\begin{array}{l}\text { 5. I listen to adults when they are } \\
\text { talking with me }\end{array}$ & 50 & 9 & 21 & 0 & 80 & 3.36 & High & 1 \\
\hline $\begin{array}{l}\text { 6. I avoid doing things with others } \\
\text { that may get me in trouble with } \\
\text { adults }\end{array}$ & 36 & 18 & 24 & 2 & 80 & 3.10 & Moderate & 3.5 \\
\hline Composite Mean & & & & & & 3.03 & Moderate & \\
\hline
\end{tabular}

\section{Legend:}

$\begin{array}{ll}1.00-1.74 & \text { Low } \\ 1.75-2.49 & \text { Fair } \\ 2.50-3.24 & \text { Moderate } \\ 3.25-4.00 & \text { High }\end{array}$


Table 1 depicted the Self-Control component among the Social Skills, the composite mean was 2.8 which was considered Moderate which also held true to all items. Among the various items in this category, the items that took the top three ranks were "I follow the teacher's directions," (3.00), followed by "I control my temper when people are angry with me" (2.94), "I end fights with my parents calmly" (2.86). Table 2 also depicted the bottom three of the Self-Control category. Least among the ranking as rated by the Grade 10 respondents was the item "I do nice things for my parents like helping with household chores without being asked" (2.66) which still belonged to Moderate level. Second, from the bottom was shared by the following items, "I take criticism from my parents without getting angry" (2.71) and "I compromise with parents or teachers when we have disagreements" (2.71). Third from the bottom was shared between the two items, namely, "I disagree with adults without ighting or arguing" (2.74) and "I make friends easily" (2.74).

The second category that was discussed is empathy, which plays a very major role when discussing social skills. Table 5 illustrated the Social Skills which was categorized as "Empathy." The composite mean in this category was 3.23 which falls on Moderate level. The top three of the items was classified as High level which were as follows, "I listen to my friends when they talk about problems they are having," (3.69), followed by "I feel sorry for others when bad things happen to them," (3.41) and "I try to understand how my friends feel when they are angry, upset, or sad" (3.29). Bottom three among the items being ranked were as follows, third from the lowest rank was, "I let friends know I like them by telling or showing them," followed by "I try to understand how my friends feel when they are angry, upset, or sad," (3.03), and the lowest among the items was, "I stand up for my friends when they have been unfairly criticized" (2.96).

In the category of Assertion as Social Skill, the Composite Mean was 2.63 which means Moderate in social skills. Top rank items were as follows, "I start talks with classroom members" (2.96), the second was "I ask friends for help with my problems" (2.90), and the third rank is, "I start conversations with opposite-sex friends without feeling uneasy or nervous" (2.84). Ranked from the bottom were as follows, third from the lowest, "I talk things over with classmates when there is a problem or an argument" (2.74), 2nd from the bottom was, "I give compliments to members of the opposite sex" (2.63), and the lowest rate is the item on "I ask someone I like for a date" (1.73) which meant Low in Social Skills in this particular category. Those items 
which belonged at the bottom three need to be addressed as the respondents were at the stage of adolescents. Greater emphasis needs to be exerted on the low ratings.

As to the respondents' propensity to Cooperation as one of the Social Skills that need to be measured, ranked highest depicts the capacity of the respondents to become good listeners to adults when the item on "I listen to adults when they are talking with me," (3.36) which was High in that Cooperation category in Social Skill. It was followed by the tendency to be respectful of the rights of others when they rated second the item on "I ask before using other people's things" (3.28) which was considered High. Third from the highest rank was a tie between items, "I avoid doing things with others that may get me in trouble with adults" and "I keep my desk clean and neat" (3.10, respectively), which were considered as Moderate. The former showed they value the highregard of adults by not putting themselves in uncompromising situations, and the latter showed that they upheld cleanliness which is one of the ways to keep adults be pleased with the respondents. The lowest rating was the item on "I finish classroom work on time."

Analyzing the overall dimensions of Social Skills, namely, Self-Control, Empathy, Assertion, and Cooperation were highly needed to come up with the overall Composite Mean.

Table 2. Summary table of the dimensions on social skills

\begin{tabular}{|c|c|c|c|}
\hline \multicolumn{5}{|c|}{$\mathrm{N}=80$} \\
\hline Items & WM & Interpretation & Rank \\
\hline Self-Control & 2.80 & Moderate & 2.5 \\
\hline Empathy & 2.80 & Moderate & 2.5 \\
\hline Assertion & 2.63 & Moderate & 3 \\
\hline Cooperation & 3.03 & Moderate & 1 \\
\hline Overall & $\mathbf{2 . 8 1}$ & Moderate & \\
\hline
\end{tabular}

Legend:

$\begin{array}{llll}\text { Mean } & \text { Acronym } & \text { Rating } & \text { Assessment Descriptor } \\ 1.00-1.74 & \text { L } & \text { Never } & \text { Low } \\ 1.75-2.49 & \text { S } & \text { Sometimes } & \text { Fair } \\ 2.50-3.24 & \text { OT } & \text { Often Times } & \text { Moderate } \\ 3.25-4.00 & \text { A } & \text { Always } & \text { High }\end{array}$


Table 2 captured the overall results of the weighted mean of all the dimensions of Social Skills. The overall composite mean was 2.81 which meant Moderate in Social Skills. Top rank was Cooperation (3.03), second in rank was a tie between Self-Control and Empathy (2.80, respectively), and the least rank was on Assertion (2.63). Such findings were not far from the results of the study of Comedis (2014) when she pointed out that among the social skills being surveyed, students most often used empathy, followed by cooperation, self-control, and assertiveness.

\section{Level of academic performance among the Junior High Respondents}

Academic performance was considered as a determinant of the academic outcomes of the Grade 10 respondents included in the study. The academic performance in this study captures grades of the second grading of school year 2017-2018.

Table 3. Level of academic performance of the respondents

\begin{tabular}{|c|c|c|c|c|c|c|c|c|c|c|}
\hline \multirow{2}{*}{$\begin{array}{c}\text { Level of } \\
\text { Performance }\end{array}$} & \multirow{2}{*}{ Rating } & \multirow{2}{*}{ Remarks } & \multicolumn{2}{|c|}{ Diligence $(n 1=24)$} & \multicolumn{2}{|c|}{ Fidelity $(\mathrm{n} 2=31)$} & \multicolumn{2}{|c|}{$\begin{array}{l}\text { Fortitude } \\
\text { (n3=25) }\end{array}$} & \multicolumn{2}{|c|}{ Total $(\mathrm{N}=80)$} \\
\hline & & & $\mathrm{F}$ & $\%$ & $\mathrm{~F}$ & $\%$ & $\mathrm{~F}$ & $\%$ & $\mathrm{~F}$ & $\%$ \\
\hline Outstanding & $90-100$ & Passed & 14 & 58.33 & 15 & 48.39 & 9 & 36.00 & 38 & 47.50 \\
\hline Very Satisfactory & $85-89$ & Passed & 6 & 25.00 & 9 & 29.03 & 7 & 28.00 & 22 & 27.50 \\
\hline Satisfactory & $80-84$ & Passed & 4 & 16.67 & 6 & 19.35 & 8 & 32.00 & 18 & 22.50 \\
\hline Fairly Satisfactory & $75-79$ & Passed & 0 & 0.00 & 0 & 0.00 & 1 & 4.00 & 1 & 1.25 \\
\hline $\begin{array}{l}\text { Did Not Meet } \\
\text { Expectations }\end{array}$ & $\begin{array}{l}\text { Below } \\
75\end{array}$ & Failed & 0 & 0.00 & 1 & 3.23 & 0 & 0.00 & 1 & 1.25 \\
\hline \multicolumn{3}{|c|}{$\mathrm{N}$} & 24 & & 31 & & 25 & & 80 & \\
\hline \multicolumn{3}{|c|}{ Mean } & 89.60 & & 88.45 & & 87.50 & & 88.50 & \\
\hline \multicolumn{3}{|c|}{ Remarks } & $\mathrm{O}$ & & VS & & VS & & VS & \\
\hline
\end{tabular}

Overall mean was 88.5 rating as to the Level of Academic Performance as shown in Table 3, almost half of the Grade 10 respondents $(47.5 \%)$ were considered as Outstanding. More than a fourth $(27.50 \%)$ were considered as Very Satisfactory, less than a fourth $(22.5 \%)$ were categorized as Satisfactory. Bottom-ranked (1.25\%) were sections Fidelity, categorized as Did Not Meet Expectations and Fortitude as Fairly Satisfactory. 
A closer look among the three sections, namely, Diligence, Fidelity, and Fortitude among the Grade 10 respondents provided the picture that the highest mean grade was with section Diligence who obtained a 89.6 rating. More than half $(58.33 \%)$ of this section had an Outstanding rating, 25 percent were at Very Satisfactory, 16.67 percent were classified as Satisfactory.

The section Fidelity was second in the overall mean grade 88.45. Almost half $(48.39 \%)$ of this section was rated as Outstanding. Almost a third $(29.03 \%)$ belonged to the Very Satisfactory level. Almost a fifth $(10.35 \%)$ were rated Satisfactory. One student in this section fell in the Did not meet Expectation category.

Last in the overall mean grade was the Fortitude section that took a mean grade of 87.5 . More than a third $(36.0 \%)$ of the class belonged to the Outstanding category. Next, almost a third (32\%) were rated as Satisfactory. Bottom-ranked were those who were rated as Very Satisfactory with 28 percent.

\section{The relationship between profile and social skills}

There were no significant relationships found utilizing Chi-Square tests as to Age and Social Skills, Sex and Social skills and Section and Social Skills.

As to the relationship between profile and academic performance, Chi-Square Tests revealed that age and section could not be associated with academic performance. 
Table 4. The relationship between sex and academic performance

\begin{tabular}{|c|c|c|c|c|c|c|c|c|}
\hline & \multicolumn{5}{|c|}{ Academic Performance } & \multirow[b]{2}{*}{ Total } \\
\hline & & & $\begin{array}{l}\text { Did Not } \\
\text { Meet } \\
\text { Expec- } \\
\text { tation }\end{array}$ & $\begin{array}{l}\text { Fairly } \\
\text { Satis- } \\
\text { factory }\end{array}$ & $\begin{array}{l}\text { Satis- } \\
\text { factory }\end{array}$ & $\begin{array}{l}\text { Very } \\
\text { Satis- } \\
\text { factory }\end{array}$ & $\begin{array}{l}\text { Out- } \\
\text { stand- } \\
\text { ing }\end{array}$ & \\
\hline \multirow{6}{*}{ Sex } & \multirow{3}{*}{ Male } & Count & 1 & 1 & 6 & 10 & 7 & 25 \\
\hline & & Expected Count & .3 & .3 & 5.3 & 6.9 & 12.2 & 25.0 \\
\hline & & $\%$ within Sex & $4.0 \%$ & $4.0 \%$ & $24.0 \%$ & $40.0 \%$ & $28.0 \%$ & $100.0 \%$ \\
\hline & \multirow{3}{*}{$\begin{array}{l}\text { Fe- } \\
\text { male }\end{array}$} & Count & 0 & 0 & 11 & 12 & 32 & 55 \\
\hline & & Expected Count & .7 & .7 & 11.7 & 15.1 & 26.8 & 55.0 \\
\hline & & $\%$ within Sex & $0.0 \%$ & $0.0 \%$ & $20.0 \%$ & $21.8 \%$ & $58.2 \%$ & $100.0 \%$ \\
\hline \multirow[t]{3}{*}{ Total } & & Count & 1 & 1 & 17 & 22 & 39 & 80 \\
\hline & & Expected Count & 1.0 & 1.0 & 17.0 & 22.0 & 39.0 & 80.0 \\
\hline & & $\%$ within Sex & $1.3 \%$ & $1.3 \%$ & $21.3 \%$ & $27.5 \%$ & $48.8 \%$ & $100.0 \%$ \\
\hline
\end{tabular}

\begin{tabular}{|l|r|r|r|}
\hline & \multicolumn{3}{|c|}{ Chi-Square Tests } \\
\hline & Value & Df & $\begin{array}{c}\text { Asymptotic Significance } \\
\text { (2-sided) }\end{array}$ \\
\hline Pearson Chi-Square & $9.807^{\text {a }}$ & 4 & .044 \\
\hline Likelihood Ratio & 10.275 & 4 & .036 \\
\hline Linear-by-Linear Association & 6.096 & 1 & .014 \\
\hline N of Valid Cases & 80 & & \\
\hline
\end{tabular}

However, as the Chi-square test was performed, a relationship was found between sex and academic performance, $X 2(4, N=80)=$ $9.807, p=0.044$. The computed $p$-value was lower than the 0.05 level of significance revealing a significant result. Thus, the null hypothesis was rejected. This suggests that there is enough evidence to show the association between sex and academic performance (See Table 4).

\section{Correlation between social skills and academic performance}

Table 5. Correlation between social skills and academic performance

$$
\mathrm{N}=80
$$

\begin{tabular}{|l|l|r|r|}
\hline \multicolumn{2}{|c|}{} & \multicolumn{1}{|c|}{ Social Skills } & Academic Performance \\
\hline \multirow{3}{*}{ Social Skills } & Pearson Correlation & 1 & -.020 \\
\cline { 2 - 4 } & Sig. (2-tailed) & & .858 \\
\cline { 2 - 4 } & $\mathrm{N}$ & 80 & 80 \\
\hline Academic Performance & Pearson Correlation & -.020 & 1 \\
\cline { 2 - 4 } & Sig. (2-tailed) & .858 & 80 \\
\cline { 2 - 4 } & $\mathrm{N}$ & 80 & 8 \\
\hline
\end{tabular}


A Pearson Product Moment Coefficient of Correlation, $r$ was computed to assess the relationship between social skills and academic performance. Results revealed that $r=-0.020, \mathrm{n}=80, p=0.858$, with $p$-value higher than the 0.05 level of significance, there was no correlation between social skills and academic performance (See Table 5). Such results ran contrary to the study of Gagnon et al., (1995), which stated that adolescents' poor emotional competence was a predictor of school difficulties being associated with underachievement in academic tasks which eventually led to school drop-out and antisocial behavior.

Furthermore, this study's findings also contradicted the findings of Malecki and Elliott (2002) who looked into the relationships among a diverse sample of elementary students' social skills, problem behaviors, academic competence, and academic achievement. They found that social skills were positively predictive of concurrent academic achievement (Malecki and Elliott, 2002).

\section{Analysis of variance of the four dimensions of social skills}

Tables 6 and 7 showed the analysis of variance of the four dimensions of social skills and multiple comparisons respectively.

Table 6. Analysis of variance of the social skills four dimensions

\begin{tabular}{|l|c|c|c|c|c|}
\hline & $\begin{array}{c}\text { Sum of } \\
\text { Squares }\end{array}$ & Df & Mean Square & F & Sig. \\
\hline Between Groups & 1.359 & 3 & .453 & 5.216 & .007 \\
\hline Within Groups & 1.998 & 23 & .087 & & \\
\hline Total & 3.356 & 26 & & & \\
\hline
\end{tabular}

A one-way ANOVA between subjects was used to compare the four dimensions of social skills. There was a significant variance of the four dimensions of social skills at the $p<0.05$ level of significance $[F(3,23)=$ $5.216, p=0.007]$ as depicted in Table 6 . 
Table 7. Analysis of variance of the social skills four dimensions - multiple comparisons

\begin{tabular}{|c|c|l|c|c|c|c|c|c|c|c|}
\hline \multicolumn{10}{|c|}{ Using Scheffe's Test } \\
\hline $\begin{array}{c}\text { Between } \\
\text { Dimensions }\end{array}$ & & Mean1 & Mean2 & D & n1 & n2 & F' & F*K-1 $^{*}$ & Interpretation \\
\hline Self-Control & vs & Empathy & 2.80 & 3.24 & -0.44 & 80 & 80 & 36.63 & 7.90 & Significant \\
\hline Self-Control & vs & Assertion & 2.80 & 2.63 & 0.16 & 80 & 80 & 5.00 & 7.90 & Insignificant \\
\hline Self-Control & vs & Cooperation & 2.80 & 3.03 & -0.24 & 80 & 80 & 10.34 & 7.90 & Significant \\
\hline Empathy & vs & Assertion & 3.24 & 2.63 & 0.61 & 80 & 80 & 68.70 & 7.90 & Significant \\
\hline Empathy & vs & Cooperation & 3.24 & 3.03 & 0.21 & 80 & 80 & 8.04 & 7.90 & Significant \\
\hline Assertion & vs & Cooperation & 2.63 & 3.03 & -0.40 & 80 & 80 & 29.73 & 7.90 & Significant \\
\hline
\end{tabular}

To determine where the variance lies, the data gathered were subjected to Scheffe's Test on the results of the four dimensions of social skills given by the Grade 10 Junior High School respondents (See Table 7). The multiple comparison tests revealed significant differences on the following: between the pairing of Self-Control and Empathy, between Self-Control and Cooperation, between Empathy and Assertion, between Empathy and Cooperation and Assertion and Cooperation. The insignificant result was yielded between Self-Control and Assertion. Studies found that the inclusion of the dimensions of social skills, such as Cooperation, Assertion, and Self-Control as measures of social skills that cut across not only Grade 10 Junior High School respondents of selfmanagement, but so with the skills in the areas of social awareness, owning the responsible making a decision and, and so with the relationship skills (Denham \& Brown, 2010).

\section{CONCLUSION}

In conclusion, the study gave an overall picture that the Grade 10 Junior High School respondents had a Moderate level of all the dimensions of Social Skills. Noteworthy to mention was their greater propensity to exercise Cooperation. A primary component of cooperative learning, positive interdependence is attained when every member of a group comes to understand and manifest the need for group cooperation in the achievement of their personal goals, the other member's goals, and the goals of the whole group (Chaiklin, 2003).

A tie of Self-Control and Empathy followed (2.80, respectively). As Rothbaum et al., (1982) presupposed that self-control is considered 
one of the most essential and beneficial capacity to adapt in the human mind. The happiest and healthiest people when looking into the optimum fit between people themselves, the environment and the possibility to improve substantially is their capacity of changing the self to fit into the world. However, they rated lowest on Assertion, specifically on asking someone for a date and complimenting the opposite sex. The persuasion which also means assertion and influence are essential skills for attitude change or others' behaviors in a desirable direction. Individual differences matter because others may not share one's views and may often behave differently from ways one prefers, most try to influence the attitudes, beliefs, or behaviors of others day by day (Baron \& Markman, 2000). Empathy is also an essential dimension of social skills. From a developmental point of view, empathy is perceived as a basic component of social interaction. It has been a point of argument that the ability to empathize in children has an essential role in the development of moral judgment, prosocial behaviors, and childhood social competence (Thompson, 1987).

No significant relationship was found between age and section to academic performance. However, there was a significant relationship between sex and academic performance. Further, social skills were not correlated with academic performance.

When comparing the four dimensions of social skills, there was a significant variance of the four dimensions. When further tested, the pairings revealed significant difference on Self-Control and Empathy, between Self-Control and Cooperation, between Empathy and Assertion, between Empathy and Cooperation and Assertion and Cooperation. Self-Control and Assertion yielded insignificant results. Hence, a need to focus on more intensive programs on developing Social Skills for the students to develop and hone a well-balanced personality.

\section{RECOMMENDATIONS}

As pointed out in a study by Zins et al., (2007), "Schools are social places, and learning is a social process." Students are learning from teachers and peers, and the utilization of emotions facilitate the learning process; the following recommendations are suggested for the Junior High School Department to initiate based on the outcomes of the study:

1. A need to focus more on the sense of assertion among the Junior High respondents as it was rated lowest. Teachers should design 
activities in the classroom where students can express their ideas and feelings without losing sight to engagement and working with others so that they can develop the tendency to complete tasks on time by voicing their insights in a cooperative learning atmosphere. Such undertaking is nurtured in an emotionally healthy learning environment that they can reach out to others/peers in completing tasks.

2. Another weak point that is noteworthy to mention is the difficulty of the respondents in reaching out to others to seek for help. A need to be expressive on what they feel and relate with others by selfdisclosure. Activities should be designed on enhancing Cooperation by transactional analysis, letting adolescents relate with others on their needs. This aspect might be challenging with the low rating. However, it would not be difficult because they rated high on empathy. Their peers can easily put themselves into the shoes of the adolescent in need. The academic community must design cocurricular and extra-curricular programs that will capacitate students to express themselves without fear and inhibition.

3. A need to design extension services that develop the creativity of students to work cooperatively with their peers, and should nurture inclusivity to avoid the repercussions of discriminations and exclusivity. Hence, the universal concept of acceptance will be improved just as is expected to happen as they enter adulthood.

4. A need to cultivate programs and activities embedded in the curriculum on how to relate with others, specifically the opposite sex. Adolescents as they are, they need guidance on how to build their self-identity and self-esteem so that they can handle their experience with the opposite sex. They can easily deal with their appreciations and likings with the "other."

5. A more vibrant Guidance Center to imbibe the sense of engagement to capacitate cooperation and assertion among adolescents, and them to maintain the balance most of the time.

6. A need to engage the family as they are the anchor of the adolescents. A need for them to understand more fully the apprehensions of their budding young adults so that they can become responsible citizens. 


\section{REFERENCES CITED}

Austin, E. J., Evans, P., Goldwater, R., \& Potter, V. (2005). A preliminary study of emotional intelligence, empathy and exam performance in firstyear medical students. Personality and Individual Differences, 39(8), 1395-1405. Retrieved from https://goo.gl/x5cBva, (accessed last 19 January 2018).

Bandura, A., \& Cervone, D. (1983). Self-evaluative and self-efficacy mechanisms governing the motivational effects of goal systems. Journal of Personality and Social Psychology, 45, 1017-1028. Retrieved from https://goo.gl/dqWbc5, (accessed last 6 February 2018).

Bandura, A., Grusec, J. E., \& Menlove, F. L. (1967). Some social determinants of self-monitoring reinforcement systems. Journal of Personality and Social Psychology, 5, 449-455. Retrieved from https://goo.gl/5ABZxJ, (accessed last 6 February 2018).

Bandura, A. (1997). Self-efficacy: The exercise of control. Macmillan.

Baron, R. A., \& Markman, G. D. (2000). Beyond social capital: How social skills can enhance entrepreneurs' success. The academy of management executive, 14(1), 106-116. Retrieved from https://goo.gl/ uTjpt5, (accessed last 16 January 2018).

Baumeister, R. F., Heatherton, T. F., \& Tice, D. M. (1994). Losing control: How and why people fail at self-regulation. San Diego: Academic Press, Inc. Retrieved from https://goo.gl/gbPjX9, (Accessed last 24 January 2018).

Bronson, M. B., Tivnan, T., \& Seppanen, P. S. (1995). Relations between teacher and classroom activity variables and the classroom behaviors of prekindergarten children in Chapter 1 funded programs. Journal of Applied Developmental Psychology, 16, 253-282. Retrieved from https://goo.gl/U4pwu7, (accessed last 16 January 2018).

Carver, C. S., \& Scheier, M. F. (1981). Attention and self-regulation: A control theory approach to human behavior. New York: Springer-Verlag. 
Retrieved from https://goo.gl/ZR1Sm6, (accessed last 24 January 2018).

Carver, C. S., \& Scheier, M. F. (1998). On the self-regulation of behavior. New York: Cambridge University Press. Retrieved from https://goo.gl/ VAm7kQ, (accessed last 24 January 2018).

Chaiklin, S. (2003). The zone of proximal development in Vygotsky's analysis of learning and instruction. Vygotsky's educational theory in cultural context, 1, 39-64. Retrieved from https://goo.gl/6DzgLL, (accessed last 10 February 2018).

Coleman JC, Hendry L. (1990). The Nature of Adolescence. 2nd edn. Florence, KY: Taylor \& Frances/Routledge.

Comedis, E. (2014). "The Role of Social Skills in the Academic Performance of De La Salle Araneta University Freshmen Students: Creating Culture." In the DLSU Research Congress De La Salle University, Manila, Philippines March, pp. 6-8. Retrieved from https://goo.gl/ XpcxXK, (accessed last 14 February 2018).

Decety, J., \& Jackson, P. L. (2004). The functional architecture of human empathy. Behavioral and Cognitive Neuroscience Reviews, 3, 71-100. Retrieved from https://goo.gl/J1qqtQ, (accessed last 10 February 2018).

Del Prette, Z. A. P., \& Del Prette, A. (1999). Inventário de habilidades sociais para adolescentes (IHSA-Del-Prette):manual de aplicação, apuração e interpretação. São Paulo: Casa do Psicólogo.

Denham, S. A. (2007). Dealing with feelings: how children negotiate the worlds of emotions and social relationships. Cognitive, Creier, Comportament/Cognition, Brain, Behavior, 11(1). Retrieved from https://goo.gl/t4XoX2, (accessed last 19 January 2018).

Denham, S. A., \& Brown, C. (2010). "Plays nice with others": Socialemotional learning and academic success. Early Education and Development, 21(5), 652-680. Retrieved from https://goo.gl/ALjLtE, (accessed last 10 February 2018). 
Gresham and Elliot M. (1990). Role of social performance in predicting learning problems: Prediction of risk using logistic regression analysis. 33(6). Retrieved from https://goo.gl/C2ASmB, (accessed last 7 February 2018).

Dyck M, Ferguson K, Shochet I. (2001) Do autism spectrum disorders differ from each other and non-spectrum disorders on emotion recognition tests? Eur Child Adolesc Psychiatry 10: 105-116. Retrieved from https://goo.gl/ddE9Hs, (accessed last 10 February 2018).

Foulks, B., \& Morrow, R. D. (1989). Academic survival skills for the young child at risk for school failure. Journal of Educational Research, 82, 158-165. Retrieved from https://goo.gl/CWChzv, (accessed last 16 January 2018).

Gagnon, C., Craig, W. M., Tremblay, R. E., Zhou, R. M., \& Vitaro, F. (1995). Kindergarten predictors of boys' stable behavior problems at the end of elementary school. Journal of Abnormal Child Psychology, 23(6), 751766. Retrieved from https://goo.gl/F25gb1, (accessed last 19 February 2018).

Hay, D. F. (1994). Pro-social development. Journal of Child Psychology and Psychiatry, 35, 29-71. Retrieved from https://goo.gl/g7E7tf, (accessed last 7 February 2018).

Heatherton, T. F. (1993). Body dissatisfaction, self-focus, and dieting status among women. Psychology of Addictive Behaviors, 7, 225-231. Retrieved from https://goo.gl/SvWwYw, (accessed last 24 January 2018).

Heatherton, T. F., \& Baumeister, R. F. (1991). Binge eating as an escape from self-awareness. Psychological bulletin, 110(1), 86. Retrieved from https://goo.gl/WbZ8fq, (accessed last 24 January 2018).

Hoffman, M. L. (1977). Sex differences in empathy and related behaviors. Psychological Bulletin, 84, 712-722. Retrieved from https://goo.gl/ CZ3ccQ, (accessed last 19 January 2018). 
Hojat, M., Mangione, S., Nasca, T. J., Cohen, M. J. M., Gonella, J. S., Erdmann, J. B., et al. (2001). The Jefferson scale of physician empathy: development and preliminary psychometric data. Educational and Psychological Measurement, 61, 349-365. Retrieved from https:// goo.gl/XWp3i3, (accessed last 19 January 2018).

Johnson, D. W., \& Johnson, R. T. (1975). Learning together and alone. Englewood Cliffs, NJ: Prentice-Hall.

Johnson, D.W., Johnson, R.T., Holubec, E.J., \& Roy, P. (1984). Circles of learning. Alexandria, VA: Association for Supervision and Curriculum Development.

Ladd, G. W., Birch, S. H., \& Buhs, E. S. (1999). Children's social and scholastic lives in kindergarten: Related spheres of influence? Child Development, 70, 1373-1400. Retrieved from https://goo.gl/9niVci, (accessed last 16 January 2018).

Lerner R, Steinberg L, editors. 2004. Handbook of Adolescent Psychology. 2nd edn. New York: Wiley.

Malecki, C. K., \& Elliot, S. N. (2002). Children's social behaviors as predictors of academic achievement: A longitudinal analysis. School Psychology Quarterly, 17(1), 1. Retrieved from https://goo.gl/wqdLBQ, (accessed last 10 February 2018).

Martens, B. K., and Witt, J. C. (2004), Competence, persistence, and success: The positive psychology of behavioral skill instruction. Psychol. Schs., 41: 19-30. Retrieved from https://goo.gl/Kphjyd, (accessed last 7 February 2018).

McLeod, S. A. (2007). BF Skinner: Operant conditioning. Retrieved September 9, 2009. Retrieved from https://goo.gl/ycMpWF, (accessed last 16 January 2018).

Minter M, Hobson R, Pring L. (1992) Recognition of vocally expressed emotion by congenitally blind children. J Vis Impair Blindness 85: 411-415. Retrieved from https://goo.gl/9qo1Ac, (accessed last 10 February 2018). 
Mischel, W., Shoda, Y., \& Peake, P. K. (1988). The nature of adolescent competencies predicted by preschool delay of gratification. Journal of Personality and Social Psychology, 54, 687-696. Retrieved from https://goo.gl/VRw9Ck, (accessed last 8 February 2018).

Rothbaum, F., Weisz, J. R., \& Snyder, S. S. (1982). Changing the world and changing the self: A two-process model of perceived control. Journal of Personality and Social Psychology, 42, 5-37. Retrieved from https://goo.gl/1YdAHf, (accessed last 24 January, 2018).

Shoda, Y., Mischel, W., \& Peake, P. K. (1990). Predicting adolescent cognitive and self-regulatory competencies from preschool delay of gratification: Identifying diagnostic conditions. Developmental Psychology, 26, 978-986. Retrieved from https://goo.gl/jHVkJR, (accessed last 10 May 2018).

Skinner, B. F. Are Theories of Learning Necessary? (1950). Psychological Review. Retrieved from https://goo.gl/npNwF7, (accessed last 8 February 2018).

Skinner, B.F.(1968). The Technology of Teaching. Appleton-CenturyCrofts, New York. Pgs. 271.

Slavin, R. E. (1995). Cooperative learning (2nd ed.). Needham Heights, MA: Allyn and Bacon. Retrieved from https://goo.gl/qvSyCX, (accessed last 10 February 2018).

Steinberg, L. (2008). A social neuroscience perspective on adolescent risk-taking. Developmental Review, 28, 78 -106. doi:10.1016/j. dr.2007 .08.002. Retrieved from https://goo.gl/bgny5y, (accessed last 15 February 2018).

Steinberg, L. (2010). A behavioral scientist looks at the science of adolescent brain development. Brain and Cognition, 72, $160-164$. Retrieved from https://goo.gl/wRTT9H, (accessed last 10 February 2018). 
Tangney, J. P., Baumeister, R. F., \& Boone, A. L. (2004). High selfcontrol predicts good adjustment, less pathology, better grades, and interpersonal success. Journal of Personality, 72(2), 271-324. Retrieved from https://goo.gl/Nw9ykk, (accessed last 24 January 2018).

Tangney, J. P., Boone, A. L., \& Baumeister, R. F. (2018). High selfcontrol predicts good adjustment, less pathology, better grades, and interpersonal success. In Self-Regulation and Self-Control (pp. 181220). Routledge. Retrieved from https://goo.gl/oukF2z, (accessed last 8 February 2018).

Thompson R. (1987) Empathy and emotional understanding: the early development of empathy. In: Eisenberg N, Strayer J, editors. Empathy and its Development. Cambridge: Cambridge University Press. $p$ 119-145. Retrieved from https://goo.gl/JVSSNt, (accessed last 10 February 2018).

Tice, D. M., \& Baumeister, R. F. (1997). A longitudinal study of procrastination, performance, stress, and health: The costs and benefits of dawdling. Psychological Science, 8, 454-458. Retrieved from https://goo.gl/3E29mZ, (accessed last 4 February 2018).

Van Rooy, D. L., Alonso, A., \& Viswesvaran, C. (2005). Group differences in emotional intelligence scores: Theoretical and practical implications. Personality and Individual Differences, 38(3), 689-700. Retrieved from https://goo.gl/Ag7zGo, (accessed last 19 January 2018).

Vygotsky, L. S. (1978). Mind in society (M. Cole, V. John-Steiner, S. Scribner, \& E. Souberman, Eds.).

Wong, C., Day, J., Maxwell, S., \& Meara, N. (1995). A multitrait-multimethod study of academic and social intelligence in college students. Journal of Educational Psychology, 87, 117-133. Retrieved from https://goo. gl/JedQoD, (accessed last 8 February 2018). 
Zins, J. E., Bloodworth, M. R., Weissberg, R. P., \& Walberg, H. J. (2007). The scientific base linking social and emotional learning to school success. Journal of Educational and Psychological Consultation, 17, 191-210. Retrieved from https://goo.gl/K9LvQ1, (accessed last 19 January 2018). 